\title{
Multicenter prospective escalation-de- escalation PET-guided clinical study in classical type Hodgkin disease in the North-West of Russian Federation (RNWOHG-HD1): rationale and design
}

Study authors: Boris V. Afanasyev ${ }^{1}$, Ivan S. Moiseev ${ }^{1}$, Sergey M. Alekseev ${ }^{2}$, Natalia B. Mikhailova ${ }^{1}$, Elena V. Kondakova ${ }^{1}$, Nikolai V. Ilyin ${ }^{3}$, Alexey M. Belyaev²

Chief scientific advisors: Boris V. Afanasyev ${ }^{1}$, Sergey M. Alekseev ${ }^{2}$, Ivan S. Moiseev ${ }^{1}$

Supervisory board: Alexey M. Belyaev ${ }^{2}$, Andrey Yu. Zaritskey ${ }^{4}$, Nikolai V. Ilyin ${ }^{3}$, Natalia B. Mikhailova ${ }^{1}$,

Nadejda V. Medvedeva ${ }^{5}$, Georgii M. Manikhas ${ }^{6}$, Sergey V. Voloshin ${ }^{7}$, Vladimir M. Moiseenko ${ }^{8}$, Tatyana V. Shneider ${ }^{9}$

${ }^{1}$ R. Gorbacheva Memorial Institute of Hematology, Oncology and Transplantation, Pavlov First St. Petersburg State Medical University, St. Petersburg, Russian Federation

${ }^{2}$ Prof. N. N. Petrov Research Institute of Oncology, St. Petersburg, Russian Federation

${ }^{3}$ Central Research Institute of X-ray and Radiation Studies, Ministry of Health of the Russian Federation, St. Petersburg, Russia ${ }^{4}$ Oncohaematology Department, Almazov Federal Heart, Blood and Endocrinology Centre, St. Petersburg, Russia

${ }^{5}$ St. Petersburg City Hospital №31, St. Petersburg, Russian Federation

${ }^{6}$ St. Petersburg City Clinical Oncology Dispensary, St. Petersburg, Russian Federation

${ }^{7}$ Russian Research Institute of Hematology and Transfusiology, St. Petersburg, Russia

${ }^{8}$ St. Petersburg Oncological Center, St. Petersburg, Russia

${ }^{9}$ Leningrad District Clinical Hospital, St. Petersburg, Russia

Dr. Ivan S. Moiseev, R. Gorbacheva Memorial Institute of Hematology, Oncology and Transplantation, First St.P etersburg State I. Pavlov Medical University, L. Tolstoy St. 6/8, 197022, St. Petersburg, Russian Federation
Phone: +7 (812) 338 6259, +7 (921) 7961951

Fax: +7 (812) 3386263

E-mail: moisiv@mail.ru

\section{Summary}

Currently there is no established standard of care for Hodgkin's disease (HD) in Russian Federation (RF). The mortality from $\mathrm{HD}$ in RF is $28,3 \%$, thus improvement of care is required. Here we describe the design and the rational for the first cooperative prospective study in the Nort-West region of RF, RNWOHG-HD1. The key points of the protocol are discussed, including escalation from ABVD to BEACOPPesc in case of PET-positive disease after first two cycles in the favorable prognosis group, and de-escalation to randomized ABVD/AVD in case of PET(-) status after first two BEACOPPesc courses in the unfavorable prognosis group. The protocol also is planned to facilitate access to second and third line treatments, including brentuximab, as well as autologous and allogeneic stem cell transplantation.

\section{Keywords}

Hodgkin's disease, multicenter study, positron emission tomography (PET), RNWOHG-HD1. 


\section{Introduction}

Treatment of classical Hodgkin's disease (HD) is one of the successful stories in hematology. Since the introduction of ABVD regimen in 1970s, the results of treatment are constantly improving [1]. Even only after ABVD regimen administered for advanced disease stages the overall survival in large patient cohorts is $78 \%$, however freedom from disease is only $66 \%$ [2], indicating the need for high-dose chemotherapy for approximately $35 \%$ of patients. This led to development of more intensive protocols, like BECOPP [3], and subsequently BEACOPPescalated and BEACOPP14 [4] that produced failure-free-survival (FFS) of $85-89 \%$ in advanced HD. Nonetheless these intensified approaches were associated with significant incidence of secondary malignancies $[5,6]$ as well as both male and female infertility [7]. This is the reason why several developed countries like the US, ABVD remains the standard of care for all disease stages [8].

The efforts to overcome the limitation of BEACOPP regimens were done after introduction of positron-emission tomography (PET) into clinical practice. It was demonstrated that PET status after two courses of chemotherapy strongly predict the outcome of treatment [9]. This finding was the foundation of several escalation studies $[10,11]$ where absence of complete response led to switching therapy from ABVD to BEACOPPesc. Also several de-escalation studies were lunched, where complete response based on PET triggered change of therapy from BEACOPPesc to ABVD [12]. These two approaches were used as the basis for protocol development by Russian North West Oncology and Hematology Group (RNWOHG).

In Russian Federation around 3200 cases of HD are documented annually, which translates into 2.2 cases per 100000 people per year. The mortality from HD is $28,3 \%$ [13], which is significantly higher than reported in the foreign registry studies. There might be several reasons for that: large distances between towns, poor excess to high-technology care, like second-line chemotherapy, autologous and allogeneic stem cell transplantation (auto and allo SCT), poor capabilities for supportive care in some of the oncology and hematology departments. In this study we wanted to solve several of these issues: coordinate the transfer of patients for the second line and to develop low toxicity protocol with relative high FFS after the first line therapy.

\section{Rationale and study design}

The study upon diagnosis separates the patients into two groups: favorable prognosis and unfavorable prognosis. The definition of favorable is different from the one of the German Hodgkin Study Group (GHSG). In this study presence stage IIB, large mediastinal mass, ESR more than $50 \mathrm{~mm} / \mathrm{h}$ and IPS [2] more than 2 places a patient into unfavorable group, while stages I-IIA without these factors are considered favorable. The reason for that is the planned omission of radiotherapy in the PET(-) patients and truncation of therapy to $4 \mathrm{ABVD}$ cycles in the group with partial response after two cycles. Thus we wanted to exclude the majority of patients who will fail this tapered therapy in the favorable arm (Fig. 1).
The treatment in the favorable arm includes two cycles of ABVD. After that the therapy is selected based on the PET status. Patients with PET(-) CR go into follow up. This decision is based on the two studies: HD10 trial and NCIC CTGECOG HD.6 trial $[14,15]$. The first study demonstrates that $2 \times A B V D$ are equivalent two $4 x A B V D$ with subsequent radiation therapy and the second that radiation therapy could be omitted after 4xABVD. These were not PET-guided studies. We believe that strict selection of good prognosis patients and verification of PET(-) status before end of therapy will produce the same results as in these two studies. Patients achieving $\mathrm{PET}(+)$ partial response undergo subsequent $2 \mathrm{xABVD}$ courses and radiation therapy, which the standard approach for the low risk responding well to the chemotherapy, used for example in HD10 study [14]. Patients that will have less then partial response after $2 \mathrm{xABVD}$ are switched to $4 \mathrm{xBEACOPPesc}$ or $4 \mathrm{xBEACOPP} 14$ according investigator choice. The efficacy of this approach was tested in the study by Johnson et al. and Italian RATHL trial $[10,16]$. In these two trials the FFS was more than $70 \%$ in all risk and stage groups, thus in the favorable group the FFS is expected to be more than $80 \%$. The omission of radiotherapy after $4 \mathrm{xBEA}$ COPPesc is based on GHSG HD12 trial, where there was no difference in FFS between radiotherapy and stop therapy groups [17]. In conclusion, based on the current data available the suggested approach should produce around $80-85 \%$ FFS in the favorable group.

The decision to leave BEACOPPesc or BEACOPP14 to an investigator choice is based on many consultations with participating centers. Several of them, which treat HD in inpatient setting were not willing to participate if there will be no option for BEACOPPesc, the other which predominantly treat $\mathrm{HD}$ in the outpatient setting were not willing to participate, if there will no option of BEACOPP14, because it is much better tolerated and could be reproduced in the outpatient facilities. In HD14 trial it was demonstrated that these two approaches are equivalent in terms of FFS [4].

Thus in the unfavorable group the therapy is started from $2 x B E A C O P P e s c$ or $2 x B E A C O P P 14$ according investigator choice. In PET(-) patients the de-escalation to ABVD/AVD cycles is planned. This is based on HD12 study, where without PET guidance switch to $4 \mathrm{xABVD}$ from $4 \mathrm{xBEACOPPesc}$ was not compromising the results, on study by Aviqdor et al. [18], and on the randomized study by Johnson et al. where in PET (-) patients there was no difference between ABVD and AVD. This is the only randomization present in the study. The expected efficacy of this approach is $85 \%$ FFS [10]. Patients who are $\mathrm{PET}(+)$ after two cycles continue BEACOPPesc/BEACOPP14 therapy up to 6 cycles. It is demonstrated in HD18 trial that the FFS is not compromised in PET(+) patients when they continued up to 8 BEACOPPesc courses [19]. In our study the therapy is limited two six cycles. This is based on the decision of opinion leaders from the participating centers. Radiation therapy is omitted after BEACOPPesc on the same basis as in the favorable arm of the study [17]. In conclusion, the unfavorable arm 1-st line is also expected to produce $80-85 \%$ FFS.

In the second line therapy four types of treatment is chosen by the investigator: DHAP, ICE, IGEV and brentuximab+ 


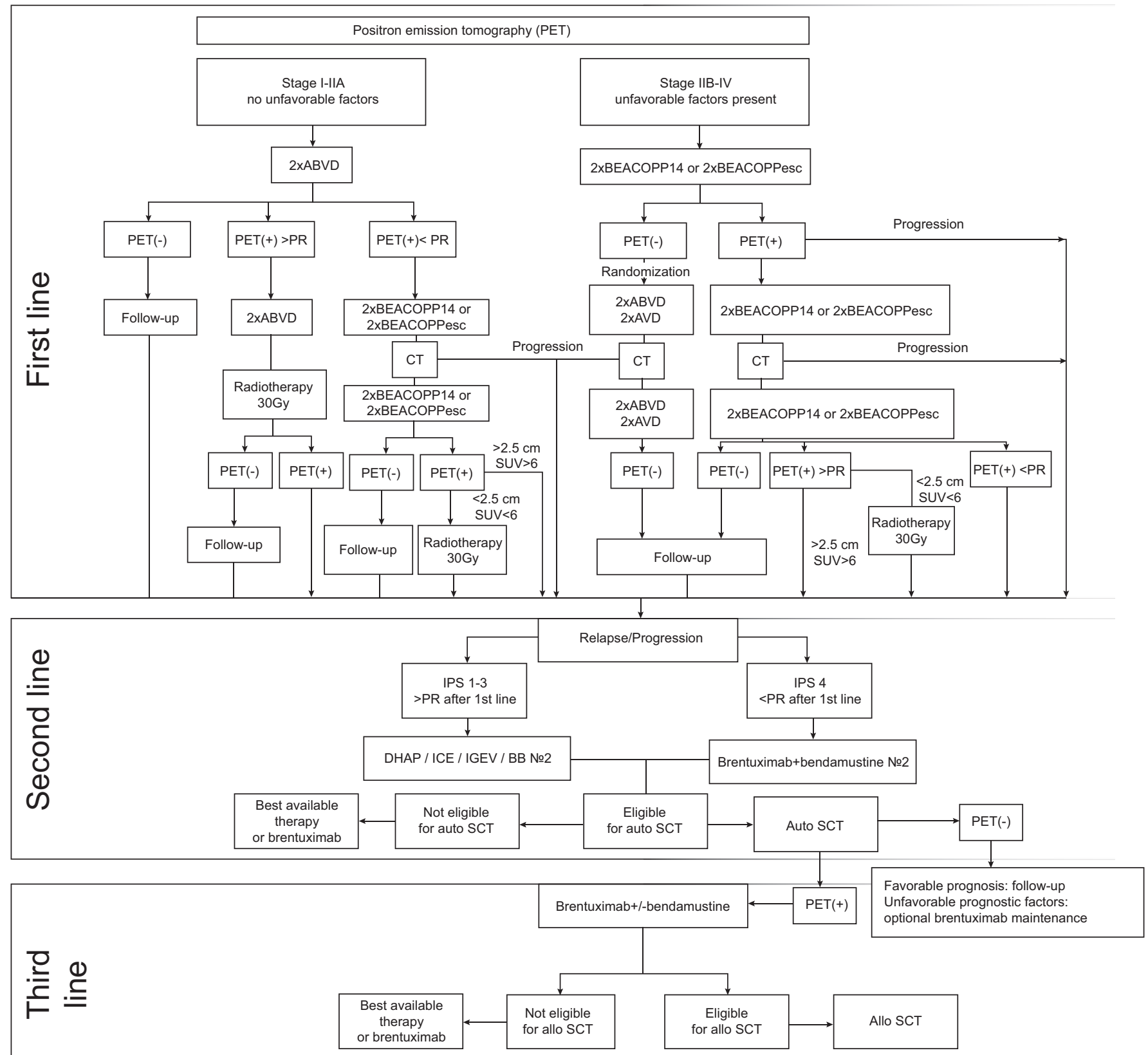

Figure 1. Study design for HIV-negative patients

bendamustine (BB). There are no restrictions in the choice of therapy since there are no large prospective randomized trials addressing this issue [20]. For patients with primary IPS $\geq 4$ and primary refractory disease the BB second line is recommended because the efficacy of standard approach with autoSCT results only in 9\% FFS in this group of patients, while $\mathrm{BB}$ protocol seems to induce higher proportion of complete responses [21-23]. The third line includes only $\mathrm{BB}$ re-induction and mandatory alloSCT from related, unrelated or haploidentical donor, whoever is available.

\section{Statistical considerations and expected results}

The study is completed with observation program which will include patients treated with conventional approaches in the participating centers. Thus it is planned to compare the re- sults of this RNWOHG-HD1 with standard care in Russian Federation. The expected overall survival in the protocol is at least $85 \%$ and the estimated enrollment is 900 patients. Thus the study is expected to demonstrate the improvement in survival with $100 \%$ power and alpha $=0.01$.

\section{HIV-infected patients}

The RNWOHG-HD1 program has the sub-study for HIV-infected patients. Since BEACOPPesc is poorly tolerated in this population of patients and results in 7\% mortality [24], all treatment in the first line is based on ABVD courses with subsequent de-escalation to randomized ABVD/AVD cycles as in the general protocol (Figure 2). The $2^{\text {nd }}$ and $3^{\text {rd }}$ line therapies are identical to the general protocol. The protocol encourages the attending physicians to control the continuation of HAART therapy throughout the whole treatment process. 


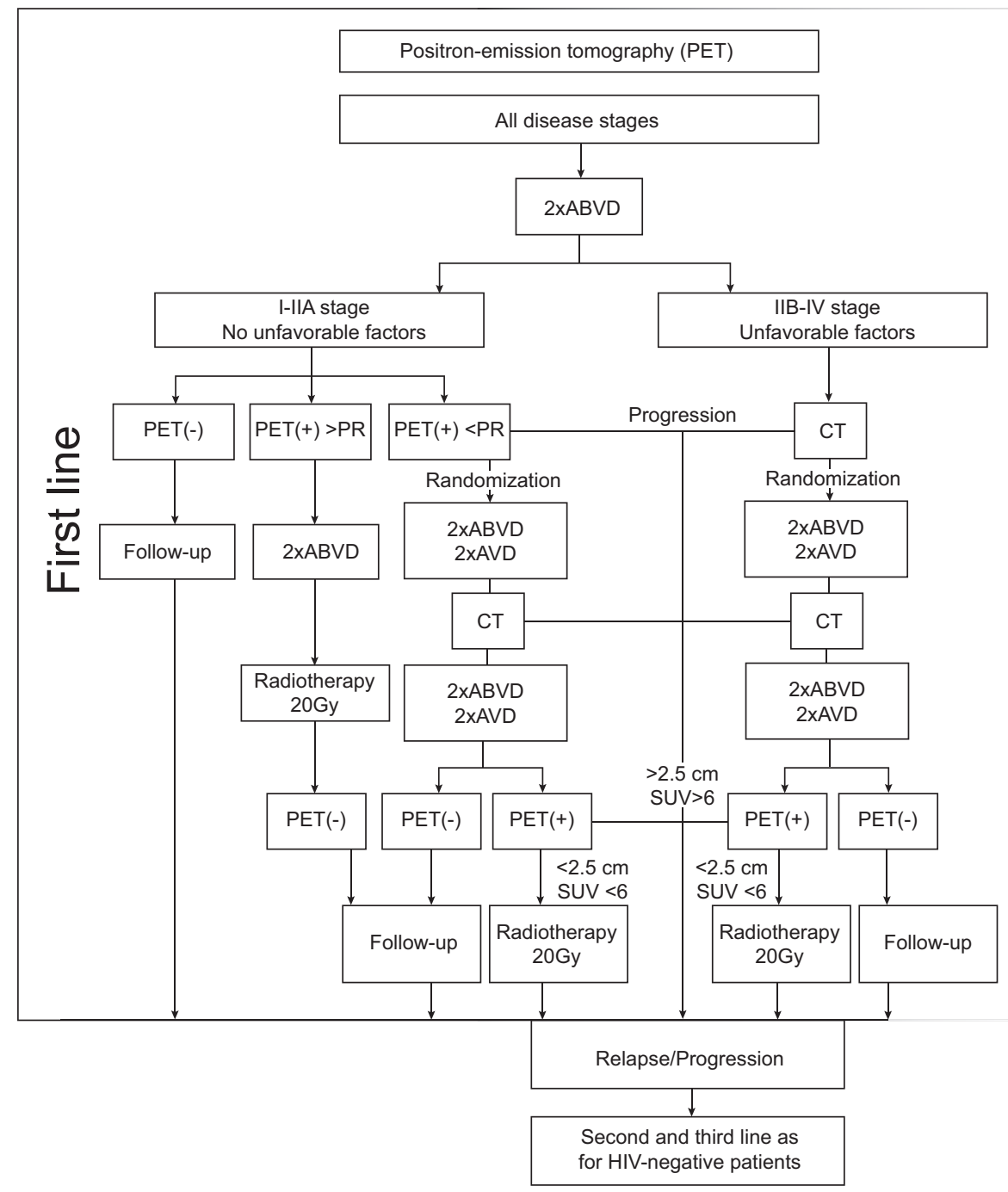

Figure 2. Study protocol for HIV-infected patients

\section{Conclusion}

In conclusion, the study is expected to improve the treatment practices in one region of Russian Federation. It is also expected to answer the questions of possible truncation of therapy based on prognostic factors and interim PET-assessed response.

\section{Acknowledgements}

The study is supported by the unrestricted grant from Takeda Inc. and is managed by Aston Health, Moscow. Special thanks to Daria Pridatchina, Dmitrii Kosov and Sofia Demura for the help in the development of the study and its electronic platform.

\section{Financial Disclosure Statement}

The authors have nothing to disclaim. Multicenter prospective escalation-de-escalation PET-guided clinical study in classical type Hodgkin disease in the Noth-Earst of Russian Federation (RNWOHG-HD1): rational and design.

\section{References}

1. Bonadonna G, Zucali R, Monfardini S et al. Combination chemotherapy of Hodgkin's disease with adriamycin, bleomycin, vinblastine, and imidazole carboxamide versus MOPP. Cancer. 1975;36(1):252-259.

2. Hasenclever D, Diehl V. A prognostic score for advanced Hodgkin's disease. International Prognostic Factors Project on Advanced Hodgkin's Disease. N Engl J Med. 1998;339(21):1506-1514.

3. Diehl V, Sieber M, Rüffer U, Lathan B, Hasenclever D, Pfreundschuh $\mathrm{M}$ et al. BEACOPP: an intensified chemotherapy regimen in advanced Hodgkin's disease. The German Hodgkin's Lymphoma Study Group. Ann Oncol. 1997;8(2):143-148.

4. Engert A, Haverkamp H, Kobe C, Markova J, Renner C, Ho A et al. Reduced-intensity chemotherapy and PET-guided radiotherapy in patients with advanced stage Hodgkin's lymphoma (HD15 trial): a randomised, open-label, phase 3 non-inferiority trial. Lancet. 2012;379(9828):1791-1799.

5. Sasse S, Klimm B, Görgen H, Fuchs M, Heyden-Honerkamp A, Lohri A et al. Comparing long-term toxicity and 
efficacy of combined modality treatment including extended- or involved-field radiotherapy in early-stage Hodgkin's lymphoma. Ann Oncol. 2012;23(11):2953-2959.

6. Dörffel W, Riepenhausenl M, Lüders H, Brämswig J, Schellong G. Secondary Malignancies Following Treatment for Hodgkin's Lymphoma in Childhood and Adolescence. Dtsch Arztebl Int. 2015;112(18):320-327.

7. Sieniawski M, Reineke T, Josting A et al. Assessment of male fertility in patients with Hodgkin's lymphoma treated in the German Hodgkin Study Group (GHSG) clinical trials. Ann Oncol. 2008;19(10):1795-1801.

8. Cheson BD. Which Hodgkin's patients in the Unites States should be treated with BEACOPP? Curr Hematol Malig Rep. 2014;9(3):222-226.

9. Gallamini A, Patti C, Viviani S, Rossi A, Fiore F, Di Raimondo $\mathrm{F}$ et al. Early chemotherapy intensification with BEACOPP in advanced-stage Hodgkin lymphoma patients with an interim-PET positive after two ABVD courses. Br J Haematol. 2011;152(5):551-560.

10. Johnson P, Federico M, Kirkwood A et al. Adapted treatment guided by interim PET-CT scan in advanced Hodgkin's lymphoma. N Engl J Med. 2016; 374(25):2419-2429.

11. Press OW, Li H, Schöder $\mathrm{H}$ et al. US Intergroup trial of response-adapted therapy for stage III to IV Hodgkin lymphoma using early interim fluorodeoxyglucose-positron emission tomography imaging: Southwest Oncology Group S0816. J Clin Oncol. 2016;34(17):2020-2027.

12. Eichenauer DA, Engert A. Advances in the treatment of Hodgkin lymphoma. Int J Hematol 2012; 96:535-543.

13. Kaprina AD, Starinskii VV, Petrova GP. Malignant neoplasms in Russia in 2015 (Morbidity and Mortality). Moscow. P.Gertcen MNIOI, 2017. ISBN 978-5-85502-227-8 (In Russian)

14. Engert A, Plütschow A, Eich HT, Lohri A, Dörken B, Borchmann $\mathrm{P}$ et al. Reduced treatment intensity in patients with early-stage Hodgkin's lymphoma. N Engl J Med. 2010;363(7):640-652.

15. Meyer RM, Gospodarowicz MK, Connors JM, Pearcey RG, Wells WA, Winter JN et al. ABVD alone versus radiation-based therapy in limited-stage Hodgkin's lymphoma. $\mathrm{N}$ Engl J Med. 2012 366(5):399-408.

16. Lugano conference presentation, Switzerland, June 1720, 2015 (abstr 008).

17. Borchmann P, Haverkamp H, Diehl V, Cerny T, Markova J, Ho AD et al. Eight cycles of escalated-dose BEACOPP compared with four cycles of escalated-dose BEACOPP followed by four cycles of baseline-dose BEACOPP with or without radiotherapy in patients with advanced-stage Hodgkin's lymphoma: final analysis of the HD12 trial of the German Hodgkin Study Group. J Clin Oncol. 2011;29(32):42344242.

18. Avigdor A, Bulvik S, Levi I, Dann EJ, Shemtov N, Perez-Avraham G et al. Two cycles of escalated BEACOPP followed by four cycles of ABVD utilizing early-interim
PET/CT scan is an effective regimen for advanced high-risk Hodgkin's lymphoma. Ann Oncol. 2010;21(1):126-132.

19. Borchmann P, Haverkamp H, Lohri A, Mey U, Kreissl S, Greil R et al. Progression-free survival of early interim PET-positive patients with advanced stage Hodgkin's lymphoma treated with BEACOPPescalated alone or in combination with rituximab (HD18): an open-label, international, randomised phase 3 study by the German Hodgkin Study Group. Lancet Oncol. 2017;18(4):454-463.

20. Engert A, Horning SJ. Hodgkin Lymphoma: A Comprehensive Update on Diagnostics and Clinics. 2011, Springer-Verlag, Berlin.

21. Zinzani PL, Vitolo U, Viviani S et al. Safety and efficacy of single-agent bendamustine after failure of brentuximab vedotin in patients with relapsed or refractory Hodgkin's lymphoma: experience with 27 patients. Clin Lymphoma Myeloma Leuk. 2015;15(7):404-408.

22. Younes A, Gopal AK, Smith SE et al. Results of a pivotal phase II study of brentuximab vedotin for patients with relapsed or refractory Hodgkin's lymphoma. J Clin Oncol. 2012;30(18):2183-2189.

23. Moskowitz CH, Nimer SD, Glassman JR et al. The International Prognostic Index predicts for outcome following autologous stem cell transplantation in patients with relapsed and primary refractory intermediate-grade lymphoma. Bone Marrow Transplant. 1999;23(6):561-567.

24. Uldrick TS, Little RF et al. How I treat classical Hodgkin lymphoma in patients infected with human immunodeficiency virus. Blood. 2015;125(8):1226-1235. 


\title{
Многоцентровое проспективное эскалационно- деэскалационное исследование с ПЭТ контролем при классической лимфоме Ходжкина в Северо-Запад- ном Федеральном Округе Российской Федерации (RNWOHG-HDI): обоснование и дизайн
}

\author{
Авторы протокола: Борис В. Афанасьев ${ }^{1}$, Иван С. Моисеев ${ }^{1}$, Сергей М. Алексеев ${ }^{2}$, Наталья Б. Михайлова ${ }^{1}$, \\ Елена В. Кондакова ${ }^{1}$, Николай В. Ильин ${ }^{3}$, Алексей М. Беляев ${ }^{2}$ \\ Главные научные кураторы: Борис В. Афанасьев ${ }^{1}$,Сергей М. Алексеев ${ }^{2}$, Иван С. Моисеев ${ }^{1}$ \\ Наблюдательный совет: Алексей М. Беляев ${ }^{2}$, Андрей Ю. Зарицкий ${ }^{4}$ Николай В. Ильин ${ }^{3}$, Наталья Б. Михайлова ${ }^{1}$, \\ Надежда В. Медведева ${ }^{5}$, Георгий М. Манихас ${ }^{6}$, Сергей В. Волошин ${ }^{7}$, Владимир М. Моисеенко ${ }^{8}$, Татьяна В. Шнейдер ${ }^{9}$ \\ ${ }^{1}$ НИИ детской онкологии, гематологии и трансплантологии, ГБОУ ВПО Первый Санкт-Петербургский государствен- \\ ный медицинский университет имени академика И. П. Павлова, Санкт-Петербург, Россия \\ ${ }^{2}$ ФБГУ Национальный медицинский исследовательский центр онкологии имени Н. Н. Петрова, \\ Санкт-Петербург, Россия \\ ${ }^{3}$ Российский научный центр радиологии и хирургических технологий имени академика А. М. Гранова, \\ Санкт-Петербург, Россия \\ ${ }^{4}$ Институт гематологии ФГБУ «НМИЦ им. В. А. Алмазова», Санкт-Петербург, Россия \\ ${ }^{5}$ Городская клиническая больница № 31, Санкт-Петербург, Россия \\ ${ }^{6}$ Городской клинический онкологический диспансер, Санкт-Петербург, Россия \\ ${ }^{7}$ Российский НИИ гематологии и трансфузиологии ФМБА России, Санкт-Петербург, Россия \\ ${ }^{8}$ Санкт-Петербургский клинический научно-практический центр специализированных видов медицинской помощи \\ (онкологический), Санкт-Петербург, Россия \\ 99 Ленинградская областная клиническая больница, Санкт-Петербург, Россия
}

\section{Резюме}

В настоящий момент на территории Российской Федерации (РФ) отсутствует стандарт лечения лимфомы Ходжкина (ЛХ). Летальность от ЛХ в РФ составляет $28,3 \%$, что свидетельствует о необходимости улучшения качества оказания медицинской помощи. В данной статье приведено описание и обоснование проспективного кооперативного исследования RNWOHG-HD1, инициированного в Северо-Западном регионе РФ. Обсуждаются ключевые моменты протокола, включая эскалацию терапии с ABVD до BEACOPPesc в случае ПЭТ-позитивности после двух циклов в группе благоприятного прогноза, и деэскалация с BEACOPPesc до AVD/ ABVD в варианте рандомизации в случае достижения ПЭТ-негативного статуса в группе неблагопри- ятного прогноза. Протокол также подразумевает координацию медицинской помощи с целью получения пациентами доступа к второй и третьей линиям терапии, включая брентуксимаб, а также доступ к аутологичной и аллогенной трансплантации гемопоэтических стволовых клеток.

\section{Ключевые слова}

Лимфома Ходжкина, многоцентровое исследование, позитронно-эмиссионная томография (ПЭТ), RNWOHG-HD1. 